INFO ARTIKEL

Riwayat Artikel:

Diterima : 15 Juni 2019

Disetujui : : 12 Agustus 2019

\title{
PENDIDIKAN
}

\section{PENERAPAN MODEL CTL (CONTEXTUAL TEACHING AND LEARNING) TERHADAP KEMAMPUAN MEMAHAMI LINGKUNGAN DAN DAERAH SEKITAR PADA SISWA KELAS XI IPS SMA YKPP TALANG UBI KABUPATEN PALI}

\author{
Bunga Adelia ${ }^{1}$, Siti Asiyah ${ }^{2}$ \\ 12 (Program Studi Pendidikan Geografi Universitas PGRI Palembang) \\ ( $\square)$ asiyahgeoadventure@gmail.com ${ }^{2}$
}

\begin{abstract}
ABSTRAK
Penelitian ini bertujuan untuk mengetahui bagaimana penerapan model CTL (Contextual Teaching and Learning) terhadap kemampuan memahami lingkungan dan daerah sekitar pada siswa kelas XI IPS SMA YKPP Talang Ubi Kabupaten PALI. Metode penelitian yang akan digunakan dalam penelitian ini adalah metode Penelitian Tindakan Kelas (PTK), terdiri dari 2 siklus yang dilaksanakan dalam empat tahapan yaitu: perencanaan, tindakan, pengamatan, dan refleksi. Subjek penelitian siswa kelas XI IS 2 berjumlah 32 siswa. Rumusan masalah: 1) bagaimana penerapan model CTL (Contextual Teaching and Learning) terhadap kemampuan memahami lingkungan dan daerah sekitar?; 2) bagaimana hasil peningkatan kemampuan memahami lingkungan dan daerah sekitar pada siswa kelas XI dalam materi mitigasi dan adaptasi bencana alam?. Tujuan penelitian untuk mengetahui 1) penerapan model CTL (Contextual Teaching and Learning) terhadap kemampuan memahami lingkungan dan daerah sekitar. 2) hasil peningkatan kemampuan memahami lingkungan dan daerah sekitar pada siswa kelas XI dalam materi mitigasi dan adaptasi bencana alam. Teknik pengumpulan data menggunakan pretes, posttes dan lembar kerja siswa. Teknik pengolahan data menggunakan rumus persentase. Hasil penelitian menunjukkan bahwa pembelajaran dengan menggunakan model pembelajaran $C T L$ memiliki dampak positif dalam meningkatkan pemahaman siswa yang ditandai dengan peningkatan ketuntasan belajar siswa pada setiap siklus, yaitu siklus I (18,75\%), siklus II (94\%). Dapat disarankan bahwa model pembelajaran CTL dapat digunakan pada pelajaran geografi.
\end{abstract}

Kata Kunci : Model Pembelajaran CTL (Contextual Teaching and Learning), Kemampuan Memahami Lingkungan

\section{PENDAHULUAN}

Geografi merupakan ilmu yang mempelajari tentang fenomena-fenomena alam yang terjadi dipermukaan bumi serta bagaimana proses terbentuknya. Ilmu geografi juga mempelajari flora dan fauna, iklim, serta kependudukan dimana geografi turut membahas mengenai hubungan antar sesama manusia, manusia dengan lingkungan dan lingkungan sebagai pemenuh kebutuhan sehari-hari manusia. Itulah mengapa ilmu geografi sangat penting untuk dipelajari serta dipahami karena ilmu geografi mempunyai peranan yang penting dalam berbagai aspek didalam kehidupan.

Menurut Sumaatmadja, (2001, dikutip dari Arta et al, 2012) bahwa studi geografi berkenaan dengan kenyataan-kenyataan yang dialami seseorang dalam perjalanan hidupnya, yang dapat dihayati sebagai kesatuan hubungan antara faktorfaktor geografi dengan umat manusia yang telah dimodifikasi, diubah, dan diadaptasikan oleh 
tindakan manusia sendiri. Ruang lingkup geografi meliputi 1) alam lingkungan yang menjadi sumber daya bagi kehidupan manusia, 2) penyebaran umat manusia dengan variasi kehidupannya, 3) interaksi keruangan umat manusia dengan alam lingkungan yang memberikan variasi terhadap ciri khas tempat-tempat permukaan bumi, dan 4) kesatuan regional yang merupakan perpaduan matra darat, perairan dan udara di atasnya. Ruang lingkup inilah yang memberikan ciri terhadap pengajaran geografi.

Dari uraian diatas dapat disimpulkan bahwa pembelajaran geografi memiliki kajian yang sangat erat kaitannya dengan alam dan segala isinya dengan memperhatikan pola spasial, kewilayahan dan lingkungan. Untuk dapat menyampaikan isi materi pembelajaran geografi perlu adanya penerapan model pembelajaran yang tepat didalam kegiatan belajar mengajar, karena materi geografi yang disajikan dengan menggunakan model yang tepat dapat memotivasi siswa untuk membentuk hubungan antara pengetahuan yang dimilikinya dan menerapkannya dengan kehidupan mereka, baik sebagai anggota keluarga, warga negara atau pekerja.

Untuk mencapai pemahaman siswa dalam materi pembelajaran geografi, peneliti menggunakan Model CTL (Contextual Teaching and Learning). Menurut Aqib (2015, dikutip dari Hamado, 2017) pendekatan pembelajaran kontekstual CTL (Contextual Teaching and Learning) merupakan konsep belajar yang membantu guru mengaitkan antara materi yang diajarkan dengan situasi dunia nyata siswa dan mendorong siswa membuat hubungan antara pengetahuan yang dimilikinya dengan penerapannya dalam kehidupan mereka sebagai anggota keluarga dan masyarakat. Hal ini mengingat bahwa penyampaian materi pembelajaran geografi tidak cukup hanya disampaikan didalam kelas dan dipahami dalam penguasan konsep saja akan tetapi siswa mampu mengaitkan materi dengan kehidupan nyata di lingkungan sekitar sehingga dapat mewariskan nilai-nilai praktik yang mampu diterapkan dalam kehidupan sehari-hari.
Berdasarkan informasi awal yang didapat dari guru yang mengajar di kelas XI IPS SMA YKPP Talang Ubi Kabupaten Pali yang menjadi permasalahan di sekolah tersebut adalah kurangnya kemampuan siswa dalam mengaitkan materi pelajaran geografi dengan lingkungan sekitar, hal ini disebabkan oleh model pembelajaran yang dapat dikatakan monoton dan tidak tepat sehingga peserta didik kurang tertarik dan cenderung bosan dalam mengikuti mata pelajaran geografi. Oleh karena itu penulis ingin meneliti lebih lanjut permasalahan tersebut dan mengetahui bagaimana penerapan model CTL (Contextual Teaching and Learning) agar siswa dapat memahami lingkungan dan daerah sekitar pada materi mitigasi dan adaptasi bencana alam.

Berdasarkan penjelasan diatas, penulis memutuskan untuk melakukan Penelitian Tindakan Kelas (PTK) dengan judul "Penerapan Model CTL (Contextual Teaching and Learning) Terhadap Kemampuan Memahami Lingkungan dan Daerah Sekitar Pada Siswa Kelas XI SMA YKPP Talang Ubi Kabupaten Pali”.

\section{METODE PENELITIAN}

Pada penelitian kali ini, peneliti menggunakan metode (PTK) Penelitian Tindakan Kelas dalam rangka melakukan perbaikan dalam proses belajar mengajar. Dalam hal ini, peneliti terjun ke lapangan secara langsung pada saat guru dan peserta didik melakukan proses pembelajaran, yaitu menggunakan bentuk kolaboratif, dengan guru sebagai mitra kerja peneliti. Penelitian tindakan kolaborasi ini merupakan suatu upaya untuk mencermati kegiatan belajar sekelompok peserta didik dengan memberikan sebuah tindakan (treatment) yang sengaja dimunculkan. Dalam penelitian ini, peneliti menggunakan Penelitian Tindakan Kelas Model Kurt Lewin. Kurt Lewin menjelaskan bahwa ada empat hal yang harus dilakukan dalam proses penelitian tindakan, yaitu: perencanaan, pelaksanaan, pengamatan dan refleksi.

Peneliti memilih menggunakan penelitian tindakan kelas model Kurt Lewin karena mudah di 
pahami dari beberapa model penelitian tindakan kelas yang lain. Dan jika dalam penelitian ini tidak berhasil bisa di lanjut ke siklus II hanya dengan merubah langkah-langkah dalam pembelajaran tanpa merubah metode, melainkan dengan menyesuaikan empat hal yang harus dilakukan dalam proses penelitian tindakan, yaitu: perencanaan, pelaksanaan, pengamatan dan refleksi (Tampubolon, 2014)

Teknik pengumpulan data merupakan bagian dari usaha yang dilakukan oleh peneliti untuk mengumpulkan data secara sistematis dimana nantinya hasil dari pengumpulan data tersebut akan dibutuhkan dalam penelitiannya dan dilakukan dengan metode observasi. Adapun di dalam penelitian ini peneliti mengumpulkan data dengan cara tes dan lembar observasi aktivitas. Tes digunakan untuk mengukur kemampuan memahami lingkungan dan daerah sekitar siswa. Sedangkan lembar observasi siswa digunakan untuk mengetahui penerapan model CTL (Contextual Teaching and Learning) yang diterapkan oleh guru dan siswa.

\section{HASIL DAN PEMBAHASAN}

Dari data observasi aktivitas siswa dan guru yang telah diamati oleh observer melalui penerapan model CTL (Contextual Teaching and Learning) yang diterapkan selama proses pembelajaran dari siklus 1 sampai siklus 2 kepada siswa menunjukan bahwa secara keseluruhan terdapat perbedaan yang meningkat terhadap kemampuan memahami lingkungan dan daerah sekitar siswa. Adapun hasil kemampuan memahami lingkungan dan daerah sekitar siswa dengan menggunakan model CTL (Contextual Teaching and Learning) yaitu terlihat dari hasil lembar observasi aktivitas siswa dimana persentase pada siklus 1 adalah 63\% dan pada siklus 2 adalah $82 \%$. Sedangkan dalam observasi aktivitas guru dengan menggunakan model CTL (Contextual Teaching and Learning) pada siklus 1 menunjukan hasil persentase yaitu $86 \%$ sedangkan siklus 2 yaitu $94 \%$.
Berdasarkan hasil yang telah diperoleh dari penelitian, menunjukan bahwa kemampuan memahami lingkungan dan daerah sekitar siswa dengan menerapkan model CTL (Contextual Teaching and Learning) memiliki presentase yang lebih tinggi pada siklus 2 dibandingkan dengan presentase siklus 1. Maka dapat disimpulkan bahwa penerapan model CTL (Contextual Teaching and Learning) yang dilakukan oleh siswa sudah mengalami peningkatan dalam pemahaman lingkungan dan daerah sekitar siswa yang ditandai dengan peningkatan presentase dari siklus 1 ke siklus 2. Model pembelajaran CTL (Contextual Teaching and Learning) sendiri menurut (Kunandar, 2009, dikutip dari Arta et al, 2012) dapat membantu guru untuk mengaitkan materi pelajaran dengan kehidupan nyata dan memotivasi peserta didik untuk mengaitkan pengetahuan yang dipelajarinya dengan kehidupan sehari-hari mereka. Pada model ini siswa dituntut untuk dapat mengaitkan materi yang diajarkan dengan kehidupan nyata yang berada dilingkungan sekitar mereka sehingga dapat diterapkan didalam kehidupan bermasyarakat. Hasil penelitianpenelitian yang telah dilakukan sebelumnya, CTL (Contextual Teaching and Learning) adalah sebuah sistem belajar yang didasarkan pada filosofi bahwa siswa mampu menyerap pelajaran apabila mereka menangkap makna dalam materi akademis yang mereka terima, dan mereka menangkap makna dalam tugas-tugas sekolah jika mereka bisa mengaitkan informasi baru dengan pengetahuan dan pengalaman yang sudah mereka miliki sebelumnya (Johnson, 2014, dikutip dari Putri dkk, 2018). Dalam proses kegiatan belajar pada penelitian ini, guru merangsang siswa agar mampu mengaitkan materi yang diajarkan dengan kehidupan nyata disekita rmereka dengan menggunakan model CTL (Contextual Teaching and Learning). Dari proses pembelajaran siklus 1 hingga siklus 2 observer mengamati aktivitas siswa yang dinilai sesuai dengan komponen didalam model CTL (Contextual Teaching and Learning.

Pada penelitian yang dilakukan oleh Putri dkk (2018) dengan judul penlitian "Pengembangan Bahan Ajar Materi Lingkungan 
Hidup Kelas XI Menggunakan Model Pembelajaran CTL di SMA Negeri 2 Mesuji". Dimana pada penelitian ini, instrumen yang digunakan adalah prototipe. Sehingga berdasarkan hasil analisis data yang telah dilakukan dapat disimpulkan bahwa siswa aktif mengikuti pelajaran menggunakan model pembelajaran CTL hasil siswa menyelesaikan soal latihan-latihan di prototipe atau buku siswa dengan nilai rata-rata 90,9 dan hasil siswa.

Pada hasil data kemampuan memahami lingkungan dan daerah sekitar siswa dalam materi mitigasi dan adaptasi bencana alam terdapat peningkatan disetiap siklus, dimana pada siklus 1 skor rata-rata ketuntasan siswa adalah 53 sedangkan pada siklus 2 skor rata-rata ketuntasan siswa adalah 79. Data tersebut didapat dari hasil nilai pretest, postest dan kerja kelompok siswa. Keunggulan penerapan model CTL juga dibuktikan oleh penelitian yang dilakukan oleh Arta dkk (2012) dengan judul penelitian "Pengaruh Penerapan Model CTL (Contextual Teaching and Learning) Berbantuan Media Pembelajaran Terhadap Hasil Belajar Geografi Siswa Kelas X di SMA Negeri 1 Nusa Penida Tapel 2012/2013". Dimana terdapat hasil peningkatan belajar dengan menggunakan model CTL yaitu skor rata-rata hasil belajar geografi siswa yang mengikuti model CTL (Contextual Teaching and Learning) berbantuan media pembelajaran mencapai 19,25 dan rata-rata skor hasil belajar geografi siswa yang mengikuti model pembelajaran konvensional mencapai 17,94 sehingga secara keseluruhan, hasil belajar geografi siswa yang mengikuti model CTL (Contextual Teaching and Learning) berbantuan media pembelajaran lebih baik daripada hasil belajar geografi siswa yang mengikuti model pembelajaran konvensional.

\section{KESIMPULAN}

Hasil penelitian menunjukkan bahwa pembelajaran dengan menggunakan model pembelajaran $C T L$ memiliki dampak positif dalam meningkatkan pemahaman siswa yang ditandai dengan peningkatan ketuntasan belajar siswa pada setiap siklus, yaitu siklus I (18,75\%), siklus II (94\%). Dapat disarankan bahwa model pembelajaran CTL dapat digunakan pada pelajaran geografi.

\section{DAFTAR PUSTAKA}

Arta; Astawa; Sutarjo. (2012). Pengaruh Penerapan Model CTL (Contextual Teaching and Learning) Berbantuan Media Pembelajaran Terhadap Hasil Belajar Geografi Siswa Kelas X di SMA Negeri 1 Nusa Penida Tapel 2012/2013. Jurnal Pendidikan. Volume $1(1): 1-11$

Aqib, Z, \& Murtadlo, A. (2016). Kumpulan Metode Pembelajaran Kreatif dan Inovatif. Bandung: PT Sarana Tutorial Nurani Sejahtera.

Hamado, Ahmad dan Ramli. (2017). Penerapan Pendekatan Pembelajaran Kontekstual Untuk Meningkatkan

Hasil Belajar Geografi Siswa Kelas XI IPS SMA Negeri 9 Kendari Pada

Materi Pokok Aspek Kependudukan: Jurnal Pendidikan. Volume 1 (1):1-19

Putri Arjunita Eka, dkk. (2018). Pengembangan Bahan Ajar Materi Lingkungan Hidup Kelas XI Menggunakan Model Pembelajaran CTL di SMA Negeri Mesuji: Jurnal Pendidikan. Volume 3 (1):2-8

Tampubolon. (2014). Penelitian Tindakan Kelas Sebagai Pengembangan Profesi Pendidik dan Keilmuan. Jakarta: Penerbit Erlangga 